\title{
Sediment Quality Assesment by Using Geochemical Index at Saguling Reservoir West Java Province Indonesia
}

\author{
Eka Wardhani ${ }^{1}$, Suprihanto Notodarmojo ${ }^{2} \&$ Dwina Roosmini ${ }^{3}$ \\ ${ }^{1}$ Post-Graduate Programme of Environmental Engineering Faculty of Civil and Environmental Engineering, \\ Institut Teknologi Bandung, Jl. Ganesha 10, Bandung 40132, Indonesia \\ ${ }^{2,3}$ Departement of Environmental Engineering, Faculty of Civil and Environmental Engineering, Institut Teknologi \\ Bandung, Jl. Ganesha 10, Bandung 40132, Indonesia \\ Correspondence: Eka Wardhani, Post-Graduate Programme of Environmental Engineering Faculty of Civil and \\ Environmental Engineering, Institut Teknologi Bandung, Jl. Ganesha 10, Bandung 40132, Indonesia. E-mail: \\ ekw_wardhani@yahoo.com
}

Received: June 25, 2018

Accepted: July 6, $2018 \quad$ Online Published: November 26, 2018

doi:10.5539/eer.v8n2p34

URL: https://doi.org/10.5539/eer.v8n2p34

\begin{abstract}
Heavy metal pollution is one of the problems that continue to occur in Indonesia which is very important because it is non-degradable, persistent, and can accumulate in the bodies of living things. Heavy metal in the water is usually present in low concentrations but human activity shall increase. Saguling Reservoir is one of the largest manmade lake in West Java Province which has experienced water contamination. The purpose of this study is to assess the quality of sediments related to the pollution of four heavy metals ie $\mathrm{Cd}, \mathrm{Cr}, \mathrm{Cu}$, and $\mathrm{Pb}$ contained in Saguling Reservoir sediment using CF, MPI, Igeo and PERI methods in the rainy and dry seasons.Sediment samples are taken in twelve points around the reservoir by 2015-2017. Based on the results of this study it can be concluded that the sediment quality of Saguling Reservoir has been contaminated by heavy metals $\mathrm{Cd}, \mathrm{Cr}, \mathrm{Cu}$, and $\mathrm{Pb}$. This is caused by human activity in the water catchment area of the reservoir. Based on the results of the analysis of sediment quality using Igeo and CF the sediment of Saguling Reservoir has been polluted by heavy metals, specifically $\mathrm{Cd}$ in the rainy and dry seasons. The result of assessment of sediment quality by MPI method can be concluded that the sediment of Saguling Reservoir as a whole has been contaminated by $\mathrm{Cd}, \mathrm{Cr}$, $\mathrm{Cu}$, and $\mathrm{Pb}$. Based on calculations using PERI method, the sediment quality of Saguling Reservoir has contaminated $\mathrm{Cd}$ with serious ecological risk category during rainy and dry season, contaminated with $\mathrm{Cr}$ and $\mathrm{Pb}$ with low grade ecologogical risk category during rainy and dry season, has been contaminated with $\mathrm{Cu}$ with low grade ecological risk in the rainy season and moderate ecological risk in the dry season. Based on the results of this study that the Cd must be cautioned carefully, because of the highest concentration in the rainy and dry season than three other heavy metals.
\end{abstract}

Keyword: contamination factor, heavy metal, index geoaccumulation, metal pollution index, potential ecological risk index, saguling, sediment

\section{Introduction}

Heavy metal pollution is one of the problems that continue to occur in Indonesia which is very important because it is non-degradable, persistent, and can accumulate in the bodies of living things. Heavy metal in the water is usually present in low concentrations but human activity shall increase its concentration in waters, in consequences shall cause of environmental problem that must been solved immediately (Luoma.,2005). Heavy metals enter the aquatic environment derived from natural processes and human activities. The enrichment of heavy metals in aquatic environments takes place through various sources: industrial waste, emissions from traffic activity, domestic waste, atmospheric deposition and others (Wei and Yang et al.,2007). Apart from human activities, important sources of natural heavy metal pollution are volcanic activity, weathering of rocks and forest fires (Shadeghi et al.,2012).

In developing countries, the rapid increase in the agricultural and industrial sectors contributes to the increase in heavy metal content in air, water, and soil (Sharma et al., 2007). Aquatic environments such as rivers, lakes and wetlands are the systems most at risk of heavy metal pollution, so understanding of heavy metal pollution in waters is an interesting topic in many parts of Asia (Sakan et al., 2015). 
All pollutants entering the waters shall accumulate the sediments which will at any time be released back into the water column and become secondary pollutants in the waters. A geochemical index has been developed to assess the quality of river/lake sediments associated with heavy metal contamination. In addition there is a method to assess the quality of sediment for the entire body of water that is Metal Pollution Index (MPI). The sediment quality assessment method has been applied in several countries such as China's Yuan River (Wang et al.,2015), China's Pearl River adjacent to Sanitary Landfills (Sayadi et al.,2015), Brazil's Doce River (Santolin et al.,2015) China's Taihu Lake (Liu et al.,2015), and China's Jiangsu River (Bo et al., 2015).

Saguling Reservoir is one of the largest manmade lake in West Java Province with its main function as Hydro Power Plant (PLTA), but along with the water requirement needs, this reservoir is used as irrigation water, floating net fishery, and final plan as raw water source for the domestic need in Bandung Basin Area. Saguling Reservoir water catchment area is the area of Bandung Basin covering the city of Bandung, Cimahi, Bandung regency, West Bandung regency and 3 subdistricts in Sumedang regency. Anthropogenic activities in the catchment area vary widely from domestic, industrial, agricultural, livestock, and mining. Waste from all of these activities ultimately boils down to the Saguling Reservoir (PT Indonesia Power., 2017).

Various types of industries are scattered in Saguling Reservoir water catchment area of 556 industries, most of which is the textile industry that is 442 industries. The industry is mostly located in Bandung regency which is 325 industries followed by Cimahi City as many as 101 industries and 90 industries in Bandung. The sources of pollution among other are the textile industry, paper industry, leather industry and food-beverage industry also have a potential source of high pollution load of organic substances, while metal and metal coating industries have the potential to dispose of heavy metal waste. Based on monitoring result of PT Indonesia Power as management institution of Saguling Reservoir, the water quality status including heavy pollution category and there are some heavy metals that do not meet the nquality standard based on Government Regulation No. 82 of 2001 regarding management of water quality and water pollution control. The purpose of this study is to assess the quality of sediments related to the pollution of four heavy metals ie $\mathrm{Cd}, \mathrm{Cr}, \mathrm{Cu}$, and $\mathrm{Pb}$ contained in Saguling Reservoir sediment using CF, MPI, Igeo and PERI methods in the rainy and dry seasons. This research is expected to provide benefits for decision makers regarding pollution conditions in the Saguling Reservoir.

\section{Materials and Methods}

Surface sediment samples were collected from twelve different sampling in Saguling lake in two seasons. The study was conducted for three years from 2015-2017. Sediment samples representing the rainy season are taken in November 2015 and April 2017 while the dry season is conducted in August 2016 and September 2017. Determination of rainy and dry seasons based on data from the agency Meteorology, Climatology, and Geophysics of West Java province. Two data taken are averaged to obtain a value that represents the rainy and dry seasons. The sampling point is selected based on the location of the water quality monitoring performed by PT. Indonesia Power. Sampling location are presented in Table 1 and Picture 1. The sampling locations were recorded (latitudinal and longitudinal position) using hand-held Global Positioning System (GPS).

Table 1. The location of sampling sites in Saguling lake

\begin{tabular}{cccc}
\hline $\begin{array}{c}\text { Sampling } \\
\text { Location }\end{array}$ & Latitude (N) & Longitude (E) & Location \\
\hline $1 \mathrm{~A}$ & $06^{\circ} 56^{\prime} 29.8^{\prime \prime}$ & $107^{\circ} 32^{\prime} 10.7^{\prime \prime}$ & Citarum River Nanjung section \\
$1 \mathrm{~B}$ & $06^{\circ} 54^{\prime} 58.9^{\prime \prime}$ & $107^{\circ} 28^{\prime} 32.3^{\prime \prime}$ & Citarum River near Batujajar \\
2 & $06^{\circ} 53^{\prime} 13.5^{\prime \prime}$ & $107^{\circ} 28^{\prime} 32.3^{\prime \prime}$ & Trash Boom Cihaur Village \\
3 & $06^{\circ} 53^{\prime} 13.4^{\prime \prime}$ & $107^{\circ} 27^{\prime} 09.0^{\prime \prime}$ & Cimerang Village \\
4 & $06^{\circ} 53^{\prime} 13.0^{\prime \prime}$ & $107^{\circ} 25^{\prime} 54.4^{\prime \prime}$ & Cihaur Estuary \\
5 & $06^{\circ} 56^{\prime} 07.6^{\prime \prime}$ & $107^{\circ} 27^{\prime} 25.5^{\prime \prime}$ & Cipantik Estuary \\
6 & $06^{\circ} 57^{\prime} 14.6^{\prime \prime}$ & $107^{\circ} 26^{\prime} 03.8^{\prime \prime}$ & Ciminyak Estuary \\
7 & $06^{\circ} 56^{\prime} 14.9^{\prime \prime}$ & $107^{\circ} 24^{\prime} 50.8^{\prime \prime}$ & Cijere Estuary \\
8 & $06^{\circ} 56^{\prime} 00.4^{\prime \prime}$ & $107^{\circ} 22^{\prime} 22.4^{\prime \prime}$ & Cijambu Estuary \\
9 & $06^{\circ} 54^{\prime} 54.4^{\prime \prime}$ & $107^{\circ} 22^{\prime} 26.3^{\prime \prime}$ & intake structure \\
$10 \mathrm{~A}$ & $06^{\circ} 51^{\prime} 49.8^{\prime \prime}$ & $107^{\circ} 20^{\prime} 57.0^{\prime \prime}$ & Trailrace \\
$10 \mathrm{~B}$ & $06^{\circ} 51^{\prime} 10.8^{\prime \prime}$ & $107^{\circ} 20^{\prime} 58.0^{\prime \prime}$ & Bantar Caringin \\
\hline
\end{tabular}

Surface Sediment samples were collected at each station by mixing four to five random samples, whereas 
composite sediments were collected from the top $10 \mathrm{~cm}$ of the surface with a grab sampler. Samples were then placed into polyethylene bags, and refrigerated at $4{ }^{\circ} \mathrm{C}$. They were analysed in the laboratory. Each sediment sample was dried at $50^{\circ} \mathrm{C}$, the samples were then grounded using pestle and mortar until all particles passed a 200-mesh nylon sieve. This fraction is mainly contained silt and clay; thus, this fraction may adsorb a higher heavy metal concentration. The extraction of heavymetals were made using conventional digestion procedure of sediment samples, which consists of digesting aliquots of $1 \mathrm{~g}$ of dry sediment was weighted into Teflon beakers, to which a mixture of concentrated $\mathrm{HNO}_{3}: \mathrm{HCl}(3: 1)$ was added and digested in a water bath during $3 \mathrm{~h}$ at $120^{\circ} \mathrm{C}$. The concentration of $\mathrm{Cd}, \mathrm{Cr}, \mathrm{Cu}$, and $\mathrm{Pb}$ were determined for each sample using an Inductively Coupled Plasma Optical Emission Spectrometry or ICP-OES.

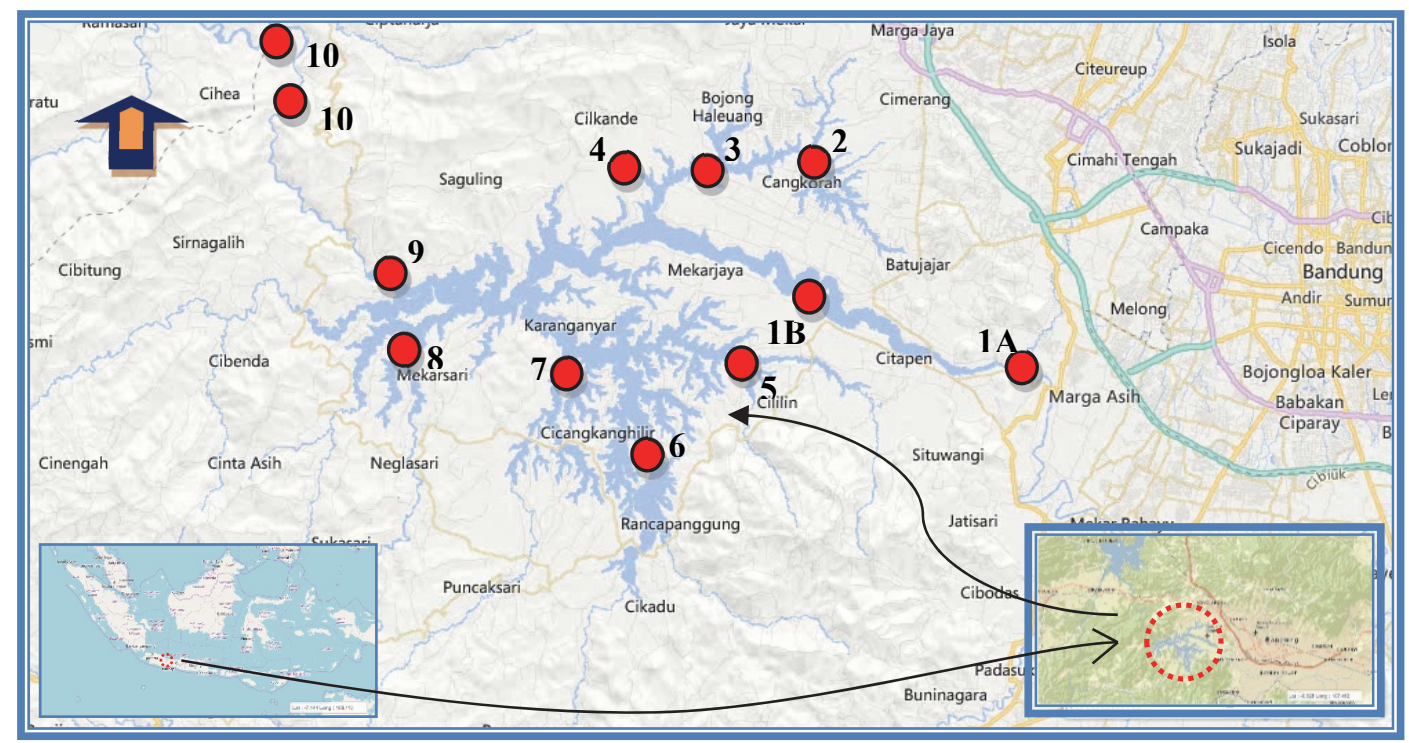

Figure 1. The location of sampling sites in Saguling Lake

The level of contamination of lake sediment by given toxic substance (metals) suggested by Hakanson, 1980 is often expressed interms of a contamination factor and is calculated as follows.

$$
C F=\frac{\text { CMetal }}{C b}
$$

Where, $\mathrm{CF}$ is the contamination factor, $\mathrm{C}_{\text {metals }}$ is the concentration of pollutants in sediment, $\mathrm{C}_{\mathrm{b}}$ is the background value for the metals. Background concentration of $\mathrm{Cd}, \mathrm{Cr}, \mathrm{Cu}$, and $\mathrm{Pb}$ was respectively $0.34 \pm 0.10 \mathrm{mg} / \mathrm{kg}$, $110.57 \pm 28.61 \mathrm{mg} / \mathrm{kg}, 49.93 \pm 9.28 \mathrm{mg} / \mathrm{kg}$, and $18.62 \pm 9.83 \mathrm{mg} / \mathrm{kg}$ based on previously research in Saguling Catcment Area. With the help of contamination factor values the intensity of contamination can be inferred (Hakanson., 1980) as follows: low contamination, $\mathrm{CF}<1$; moderate contamination $1<\mathrm{CF}<3$; considerable contamination, $3<\mathrm{CF}<6$; and very high contamination, $\mathrm{CF}>6$.

Metal Pollution Index (MPI) is defined as the root of the product of the CF. Tomlinson, 1980 has developed a simple method based on MPI to assess the degree of pollution by metals in aquatic sediments, MPI was calculated using the equation 2 where $n$ the number of metals.

$$
\mathrm{PLI}=\left(\mathrm{CF}_{1} \times \mathrm{CF}_{2} \times \mathrm{CF}_{3} \ldots \ldots \ldots \times \mathrm{CF}_{\mathrm{n}}\right)^{1 / \mathrm{n}}
$$

A value of on the PLI would indicated no pollutants; a value of 1 would suggest the presence of baseline levels of pollutants, while value that exceed 1 would indicated a progressive deterioration of the site and lake (Tomlinson et al.,1980).

The geo-accumulation index (Igeo) and potential ecological risk index (PERI) were used to assess the degree of heavy metal contamination in the Saguling Lake sediments collected in this study. The Igeo is defined by the following equation:

$$
\text { Igeo }=\frac{\log 2(\mathrm{Cn})}{1.5 C b}
$$


where $\mathrm{Cn}$ is the concentration of heavy metals in the sediment and $\mathrm{Cb}$ is the background concentration of the heavy metal. Background concentration of $\mathrm{Cd}, \mathrm{Cr}, \mathrm{Cu}$, and $\mathrm{Pb}$ was respectively $0.34 \pm 0.10 \mathrm{mg} / \mathrm{kg}, 110.57 \pm 28.61 \mathrm{mg} / \mathrm{kg}$, $49.93 \pm 9.28 \mathrm{mg} / \mathrm{kg}$, and $18.62 \pm 9.83 \mathrm{mg} / \mathrm{kg}$ based on previously research in Saguling Catcment Area. Factor 1.5 is the background matrix correction factor due to lithospheric effects. Müller (Muller et al., 1981) distinguished seven classes of the I-geo classes: Class 0 (practically uncontaminated): Igeo 0; Class 1 (uncontaminated to moderately contaminated): $0<$ Igeo $<1$; Class 2 (moderately contaminated): $1<$ Igeo $<2$; Class 3 (moderately to heavily contaminated): $2<$ Igeo $<3$; Class 4 (heavily contaminated): $4<$ Igeo $<5$; Class 5 (heavily to extremely contaminated): $4<$ Igeo $<5$; and Class 6 (extremely contaminated): Igeo $>5$.

Hakanson proposed the PERI in 1980, and it has since been applied to evaluate the harm caused by heavy metals in sediments (Fernandez et al., 1997; Zhu et al., 2012). The method was widely used and is described below:

$$
\text { PERI }=\sum_{n=1}^{n}\left(\text { Tix } \frac{C i}{C b}\right)
$$

Ti, the toxic-response index from Hakanson (Hakanson, 1980), PERI was adopted as the evaluation criterion in this study $(\mathrm{Cd}=30, \mathrm{Cu}=\mathrm{Pb}=\mathrm{Ni}=5, \mathrm{Cr}=2, \mathrm{Zn}=1)$ (Zhao et.al.,2005); $\mathrm{Ci}$ was the measured values of heavy metals in the surface sediments; and $\mathrm{Cb}$ is regional background value of heavy metals for calculation. Background concentration of $\mathrm{Cd}, \mathrm{Cr}, \mathrm{Cu}$, and $\mathrm{Pb}$ was respectively $0.34 \pm 0.10 \mathrm{mg} / \mathrm{kg}, 110.57 \pm 28.61 \mathrm{mg} / \mathrm{kg}, 49.93 \pm 9.28 \mathrm{mg} / \mathrm{kg}$, and $18.62 \pm 9.83 \mathrm{mg} / \mathrm{kg}$ based on previously research in Saguling Catcment Area. The ranking standard of the potential ecological risk index of heavy metals ranged from class 1-4: Class 1 (low-grade ecological risk): PERI $<150$; Class 2 (moderate ecological risk): $150<\mathrm{PERI}<300$; Class 3 (severe ecological risk): $300<\mathrm{PERI}<600$; and Class 4 (serious ecological risk): PERI $>600$.

\section{Result and Discussion}

The Saguling Reservoir is one of three reservoirs in the Citarum River. Saguling Reservoir is also the first reservoir that holds water Citarum River. The residents utilize the reservoir water potential for fish cultivation business, especially fisheries and is very helpful for the improvement of the society economy in the coastal reservoir. In addition, the function of the saguling reservoir is as a source of water for hydropower (hydropower) that can generate electrical energy for Java and Bali electricity systems, irrigation water for Cianjur and surrounding areas, as well as tourism (PT Indonesia Power., 2016). There are 7 rivers that enter the Saguling Reservoir, the largest of which is Citarum River, other rivers are Cimerang, Cihaur, Cipatik, Ciminyak, Cijere and Cijambu. Currently, the water quality of Saguling Reservoir tends to decrease, either as a result of pollution by industrial waste, household, agriculture, and mining, and residual feed from fish farming, while quantity is the factor of decreasing the amount or volume of water, specifically in a long dry season which often happens in the last few years. It is known that along the Citarum River to Nanjung (127 km 47.1\% of river length) has been categorized as heavy polluted (PT Indonesia Power.,2017). The main source of Saguling Reservoir water comes from Upper Citarum River. This river is a river segment along the $77 \mathrm{~km}$ stretching from the Citarum River upstream that is Situ Cisanti in Kertasari Sub-district of Bandung Regency up to Nanjung which is the Saguling Reservoir inlet (PT Indonesia Power.,2015). The Upper Citarum River Basin is the area of the Bandung Basin. Anthropogenic activities in the Upper Citarum Basin vary greatly from domestic, industrial, agricultural, livestock, and mining. Waste from all of these activities eventually went into the Upper Citarum River and empties into the Saguling Reservoir (West Java Regional Environmental Control Agency.,2015). The characteristics of the Saguling Reservoir are presented in Table 2.

Table 2. The Characteristic of Saguling Reservoir

\begin{tabular}{llll}
\hline No. & Parameter & Unit & Point \\
\hline 1 & Reservoir large $( \pm 643 \mathrm{~m})$ & $\mathrm{ha}$ & 5.607 \\
2 & Maximum length & $\mathrm{km}$ & 18,4 \\
3 & Average width & $\mathrm{km}$ & 3,0 \\
4 & Maximum depth & $\mathrm{m}$ & 90 \\
5 & Average depth & $\mathrm{m}$ & 17,5 \\
6 & Maximum voilume & $\mathrm{x} \mathrm{1} 0^{6} \mathrm{~m}^{3}$ & 982 \\
7 & Watershed area & $\mathrm{km}^{2}$ & 2.315 \\
\hline
\end{tabular}

Source: PT Indonesia Power.,2015

The concentration of $\mathrm{Cd}$ in the sediment of Saguling Reservoir in the rainy season ranged from $11.43-16.68 \mathrm{mg} / \mathrm{kg}$ 
with an average value of $14.82 \pm 1.48 \mathrm{mg} / \mathrm{kg}$. The lowest value is at point $10 \mathrm{~B}$ (Bantar Caringin) of $11.43 \mathrm{mg} / \mathrm{kg}$ and the highest is at point 4 (Cihaur Estuary) of $16.68 \mathrm{mg} / \mathrm{kg}$. Compared with the quality standard based on ANZECC ISQG-Low, $1997 \mathrm{Cd}$ concentrations at 12 observation points did not meet the established standard of $1.5 \mathrm{mg} / \mathrm{kg}$. The dry season average Cd concentration is lower than the rainy season which is $11.12 \pm 2.16 \mathrm{mg} / \mathrm{kg}$. The concentration of $\mathrm{Cd}$ ranged from $8.10-15.47 \mathrm{mg} / \mathrm{kg}$ with the lowest concentration found at point 8 (Cijambu Estuary) and the highest concentration was at point 10B (Bantar Caringin). Similar to the rainy season Compared with the quality standard based on ANZECC ISQG-Low, $1997 \mathrm{Cd}$ concentrations at 12 observation points did not meet the established standard of $1.5 \mathrm{mg} / \mathrm{kg}$ as presented in Table 3 .

Source Cd contained in the Saguling Reservoir comes from human activities and natural sources. Domestic, industrial, agricultural, and mining activities in the catchment area contribute to the Cd contamination load in the reservoir. On the other hand, the source of contamination of heavy metals and other pollutant materials is also predicted to come from the process of leaching of volcanic activity such as Mount Tangkuban Perahu, Wayang, and Patuha capable of carrying sulfate compound content to the Citarum River of 6,000-12,000 ppm, Chloride 5,300-12,600 ppm, and heavy metals, among others: $\mathrm{As}, \mathrm{Ba}, \mathrm{Mg}, \mathrm{Al}, \mathrm{Cu}, \mathrm{Pb}, \mathrm{Zn}, \mathrm{Hg}$, Se, and $\mathrm{Cd}$ (Sriwana, 1999). According to Alloway, $1995 \mathrm{Cd}$ source can be derived from fertilizer on farmland, lime, and compost with value of Cd concentration derived from phosphate fertilizer of $0.10-170 \mathrm{mg} / \mathrm{kg}$, nitrate of $0.05-8.50 \mathrm{mg} / \mathrm{kg}$, fertilizer from farm $0.10-0.80 \mathrm{mg} / \mathrm{kg}$, from composting waste of $0.01-100 \mathrm{mg} / \mathrm{kg}$, and from lime of $0.04-0.10 \mathrm{mg} / \mathrm{kg}$. Chemical fertilizer of the super-phospate group can contaminated the sediment because they contain 0.05 to 170 $\mathrm{mg} \mathrm{Cd} / \mathrm{kg}$.

Table 3. Analisys Result of Statistic Concentrates of $\mathrm{Cd}, \mathrm{Cr}, \mathrm{Cu}$, dan $\mathrm{Pb}$ in Sediment Saguling Reservoir at Two Different Seasons

\begin{tabular}{|c|c|c|c|c|c|c|c|c|}
\hline \multirow{2}{*}{ Sampling Location } & \multicolumn{2}{|c|}{ Cd } & \multicolumn{2}{|c|}{$\mathrm{Cr}$} & \multicolumn{2}{|c|}{$\mathbf{C u}$} & \multicolumn{2}{|c|}{$\mathbf{P b}$} \\
\hline & Rainy & Dry & Rainy & Dry & Rainy & Dry & Rainy & Dry \\
\hline $1 \mathrm{~A}$ & 16.46 & 13.98 & 165.25 & 189.05 & 106.74 & 263.18 & 18.59 & 73.88 \\
\hline 1B & 16.32 & 11.56 & 136.81 & 122.34 & 150.32 & 157.79 & 27.75 & 34.75 \\
\hline 2 & 15.44 & 11.82 & 118.27 & 103.84 & 143.58 & 244.47 & 27.70 & 38.78 \\
\hline 3 & 14.23 & 12.00 & 121.45 & 156.02 & 73.43 & 156.37 & 17.17 & 21.39 \\
\hline 4 & 16.68 & 12.01 & 146.14 & 127.30 & 129.00 & 158.75 & 29.56 & 33.94 \\
\hline 5 & 15.37 & 9.06 & 134.50 & 103.45 & 85.12 & 89.49 & 23.98 & 25.47 \\
\hline 6 & 14.02 & 8.64 & 120.24 & 94.15 & 127.16 & 95.85 & 22.35 & 23.05 \\
\hline 7 & 15.43 & 10.56 & 145.09 & 97.12 & 125.02 & 133.41 & 40.20 & 24.49 \\
\hline 8 & 13.71 & 8.10 & 120.03 & 92.02 & 82.47 & 69.53 & 18.23 & 13.54 \\
\hline 9 & 14.93 & 9.67 & 132.21 & 116.02 & 153.04 & 135.18 & 23.22 & 20.05 \\
\hline $10 \mathrm{~A}$ & 13.86 & 10.65 & 124.47 & 113.47 & 79.37 & 154.28 & 28.62 & 20.95 \\
\hline 10B & 11.43 & 15.47 & 94.74 & 162.65 & 61.43 & 165.18 & 27.88 & 19.81 \\
\hline Standard* & 1.50 & 1.50 & 80.00 & 80.00 & 65.00 & 65.00 & 50.00 & 50.00 \\
\hline Mean & 14.82 & 11.12 & 129.93 & 123.12 & 109.72 & 151.95 & 25.43 & 29.17 \\
\hline Deviation Standard & 1.48 & 2.16 & 17.79 & 30.74 & 32.34 & 56.95 & 6.36 & 15.85 \\
\hline Minimum & 11.43 & 8.10 & 94.74 & 92.02 & 61.43 & 69.53 & 17.17 & 13.54 \\
\hline Maximum & 16.68 & 15.47 & 165.25 & 189.05 & 153.04 & 263.18 & 40.20 & 73.88 \\
\hline
\end{tabular}

*ANZECC ISQG-Low.,1997

Based on Table 3 the average concentration of $\mathrm{Cr}$ in the sediment of Saguling Reservoir in the rainy season is higher than the dry season, the rainfall $\mathrm{Cr}$ concentration reaches $129.93 \pm 17.79 \mathrm{mg} / \mathrm{kg}$ while in the dry season it is $123.12 \pm 30.74 \mathrm{mg} / \mathrm{kg}$. Cr concentration in the rainy season ranges from $94.74-165.25 \mathrm{mg} / \mathrm{kg}$ while dry season $92.02-189.05 \mathrm{mg} / \mathrm{kg}$. In rainy season and dry season the highest $\mathrm{Cr}$ concentration is at point $1 \mathrm{~A}$ (Citarum River Nanjung section) while the lowest concentration in rainy season is at point 10B (Bantar Caringin) and dry season 
is at point 8 (Cijambu Estuary). Cr concentration in the Saguling Reservoir sediment did not meet the standards compared to ANZECC ISQG-Low, 1997, Cr concentration at 12 observation points did not meet the established standard of $80 \mathrm{mg} / \mathrm{kg}$. The high concentration of $\mathrm{Cr}$ is predicted to come from various industrial activities, especially the textile industry spread in Saguling Reservoir, especially that through the Citarum River.

The average $\mathrm{Cu}$ concentration in the sediment of Saguling Reservoir in the rainy season is lower than the dry season, in the rainy season the average $\mathrm{Cu}$ concentration is $109.72 \pm 32.34 \mathrm{mg} / \mathrm{kg}$ while in the dry season it reaches $151.95 \pm 56.95 \mathrm{mg} / \mathrm{kg}$. The concentration range in the rainy season at 12 research points ranged from 61.43-153.04 $\mathrm{mg} / \mathrm{kg}$ with the lowest concentration being at the point of 10B (Bantar Caringin) and the highest in point 9 (intake structure). $\mathrm{Cu}$ concentrations in the dry season ranged from $69.53-263.18 \mathrm{mg} / \mathrm{kg}$ with the lowest concentration found at point 8 (Cijambu Estuary) and highest in tititk 1A (Citarum River Nanjung section). Cu concentrations in the Saguling Reservoir sediment did not meet the quality standard when compared with ANZECC ISQG-Low, 1997, $\mathrm{Cu}$ concentrations at 12 observation points did not meet the established standards of $65 \mathrm{mg} / \mathrm{kg}$. Only one point that meets quality standard is at point 10B (Citarum River near Batujajar) in the rainy season. The high concentration of $\mathrm{Cu}$ is predicted to come from various industrial activities, especially the textile industry spread in Saguling Reservoir, especially through the Citarum River.

The average $\mathrm{Pb}$ concentration in the sediment of Saguling Reservoir in the rainy season is lower than the dry season. In the rainy season the average $\mathrm{Pb}$ concentration is $25.43 \pm 6.36 \mathrm{mg} / \mathrm{kg}$ while in the dry season it reaches $29.17 \pm 15.85 \mathrm{mg} / \mathrm{kg}$. The concentration range in the rainy season at 12 research points ranged from 17.17-40.20 $\mathrm{mg} / \mathrm{kg}$ with the lowest concentration being at point 3 (Cimerang Village) and highest in point 7 (Cijere Estuary). The concentration of $\mathrm{Pb}$ in the dry season ranged from $13.54-73.88 \mathrm{mg} / \mathrm{kg}$ with the lowest concentration at point 8 (Cijambu Estuary) and the highest was in point $1 \mathrm{~A}$ (Citarum River Nanjung section). The concentration of $\mathrm{Pb}$ in the Saguling Reservoir sediment meets quality standard when compared to ANZECC ISQG-Low, 1997 at 50 $\mathrm{mg} / \mathrm{kg}$.

Picture 2 to 5 present concentrations of $\mathrm{Cd}, \mathrm{Cr}, \mathrm{Cu}$, and $\mathrm{Pb}$ in the Saguling Reservoir during the rainy and dry seasons. Judging from the average value of the order of the largest concentration to the smallest in the rainy season is $\mathrm{Cr}>\mathrm{Cu}>\mathrm{Pb}>\mathrm{Cd}$ while in the dry season is $\mathrm{Cu}>\mathrm{Cr}>\mathrm{Pb}>\mathrm{Cd}$. Based on the drawings the average concentration of $\mathrm{Cd}$ and $\mathrm{Cr}$ in the Saguling Reservoir sediment in the rainy season is higher than the dry season, but for $\mathrm{Cu}$ and $\mathrm{Pb}$ shall apply the opposite condition. High $\mathrm{Cd}$ and $\mathrm{Cr}$ concentrations in the rainy season are predicted to be caused by the entry of these metals into the Saguling Reservoir from rivers in the Saguling Reservoir water catchment area. The average concentration of $\mathrm{Cu}$ and $\mathrm{Pb}$ which is lower in the rainy season than the dry season should be investigated further because the phenomenon should be the same as $\mathrm{Cd}$ and $\mathrm{Cr}$.

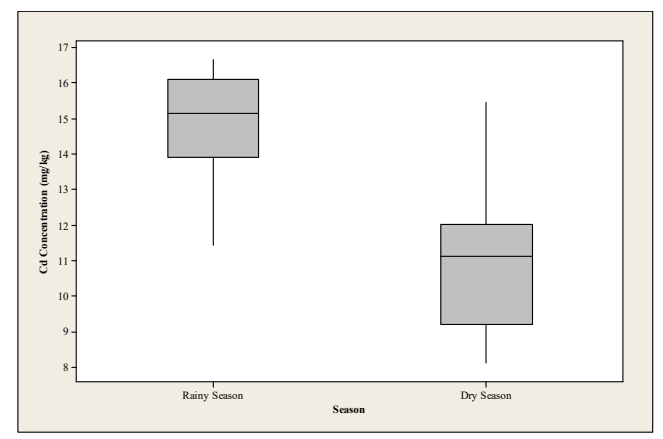

a

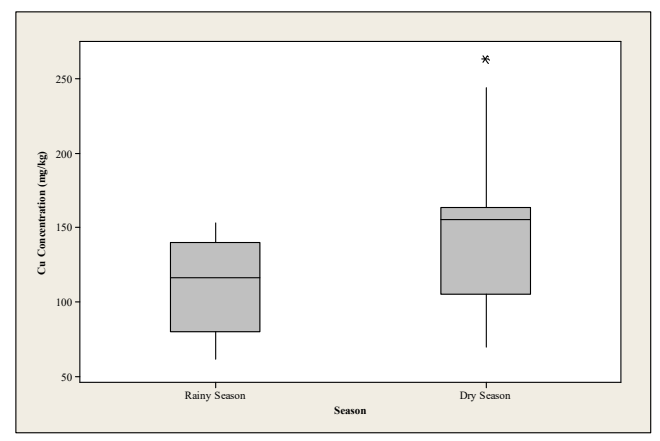

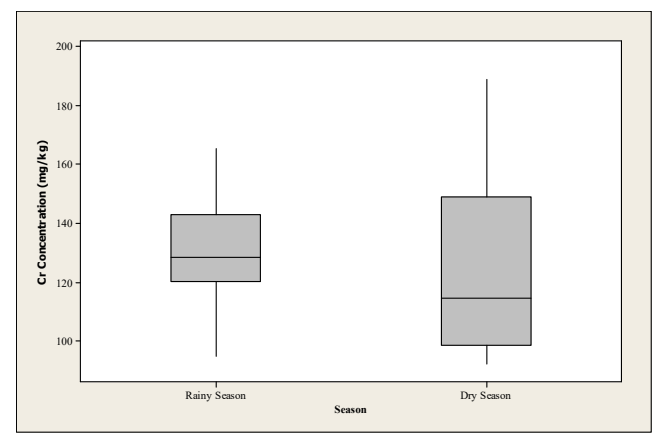

b

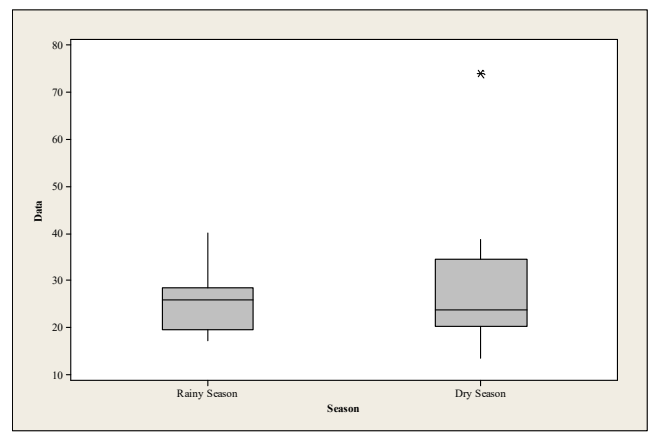


Figure 2. a) Cd Concentration in Saguling Lake Sediment b) Concentration in Saguling Lake Sedimen c) Cu Concentration in Saguling Lake Sediment D Pb Concentration in Saguling Lake Sediment

The heavy metals that accumulate in the Saguling Reservoir sediment are predicted to come from the catchment areas that mainly enter through the Upper Citarum River. Based on data from West Java Provincial Environment Agency, the number of industries scattered in the Citarum Basin is 556 industries, of which 442 industries are the largest. sources of pollution. The textile industry, paper industry, leather industry and food-beverage industry have the potential as a source of high pollution load of organic substances, while metal and metal coating industries have the potential to dispose of heavy metal waste. Table 4. describes industry type groups in the Upper Citarum watershed.

Table 4. Industrial Type of Group at Das Citarum Upstream

\begin{tabular}{|c|c|c|c|c|c|c|c|c|}
\hline Location & Textile & $\begin{array}{c}\text { Pulp } \\
\text { and } \\
\text { paper }\end{array}$ & $\begin{array}{l}\text { Leather } \\
\text { Tanning }\end{array}$ & $\begin{array}{c}\text { Rubber } \\
\text { and } \\
\text { Plastic }\end{array}$ & Chemical & $\begin{array}{l}\text { Metal and } \\
\text { Electronic }\end{array}$ & $\begin{array}{c}\text { Food } \\
\text { and } \\
\text { Beverage }\end{array}$ & Jumlah \\
\hline Bandung Regency & 274 & 5 & 8 & 11 & 6 & 15 & 6 & 325 \\
\hline Bandung Municipality & 64 & 3 & 1 & 0 & 2 & 15 & 5 & 90 \\
\hline Cimahi Municipality & 75 & 0 & 1 & 3 & 2 & 9 & 11 & 101 \\
\hline West Bandung & & & & & & & & \\
\hline Regency & 16 & 0 & 0 & 0 & 4 & 1 & 2 & 23 \\
\hline Sumedang Regency & 13 & 0 & 1 & 2 & 0 & 0 & 1 & 17 \\
\hline Jumlah & 442 & 8 & 11 & 16 & 14 & 40 & 25 & 556 \\
\hline
\end{tabular}

West Java Regional Environmental Control Agency, 2017.

Based on wastewater Permit (IPLC) which is regulated by the Ministry of Environment and Forestry of Republic Indonesia for wastewater producing institutions of industrial activity which predicted to produce metals such as textile industry, leather tanning, and metal and electronic industry. Textile industry has the potential to produce wastewater containing BOD5, COD, TSS, Phenol, Chromium Total (Cr), Total Ammonia (NH3-N), Sulfide (S), Oil and Grease, $\mathrm{pH}$, Manufacture of tannery produce waste water containing BOD5, COD, TSS, Chromium Total (Cr), Oil and Grease, Nitrogen total, Ammonia total, Sulfide (S), pH, and electroplatting have the potential to produce wastewater containing TSS, Cyanide $(\mathrm{CN})$, Chromium total $(\mathrm{Cr})$, Chromium hexavalen $(\mathrm{Cr}+6)$, Copper $(\mathrm{Cu})$, Zinc (Zn), Nickel (Ni), Cadmium (Cd), Lead (Pb), and pH.

Research on the quality of heavy metals in lake sediments has been widely practiced in several countries, Table 5 summarizes the results of research on heavy metal concentrations in several countries. Based on Table 5, the concentration value of $\mathrm{Cd}, \mathrm{Cr}$, and $\mathrm{Cu}$ contained in the Saguling Reservoir occupies the highest position compared with other lakes while for $\mathrm{Pb}$ the highest concentration in China's Chaohu Lake.

Table 5. Heavy Metal Concentration in Lake Sediment of some Countries

\begin{tabular}{|c|c|c|c|c|c|c|}
\hline \multirow{2}{*}{ No } & \multirow{2}{*}{ Lake Names } & \multicolumn{4}{|c|}{ Heavy Metal Concentration (mg/kg) } & \multirow{2}{*}{ Source } \\
\hline & & Cd & $\mathrm{Cr}$ & $\mathrm{Cu}$ & $\mathbf{P b}$ & \\
\hline 1 & Texoma, USA & 2.00 & 30 & 38 & 10 & Yin dkk, 2011 \\
\hline 2 & Taihu, China & 0.94 & 56,2 & 36,7 & 51,8 & Yin dkk, 2011 \\
\hline 3 & Veeranam, India & 0.81 & 88,2 & 94,12 & 30,06 & Suresh dkk, 2010 \\
\hline 4 & Chaohu, China & 0.92 & 80,1 & 38,6 & 94,9 & Zheng dkk, 2010 \\
\hline 5 & Manchar, Pakistan & $1.00-4.00$ & $14,7-26,8$ & $15,6-29,7$ & $14,6-20,9$ & Arain dkk, 2008 \\
\hline 6 & Balaton, Hungary & 0.06 & $5,7-66$ & $0.7-36$ & $2,4-160$ & Nguyen dkk, 2005 \\
\hline \multirow[t]{3}{*}{7} & Saguling Lake & & & & & \\
\hline & Rainy Season & $14.82 \pm 1.48$ & $129.93 \pm 17.79$ & $109.72 \pm 32.34$ & $25.43 \pm 6.36$ & \\
\hline & Dry Season & $11.12 \pm 2.16$ & $123.12 \pm 30.74$ & $151.95 \pm 56.95$ & $29.17 \pm 15.85$ & This Study \\
\hline
\end{tabular}

The presence of heavy metals in the sediment of Saguling Reservoir should be on the alert because the function of 
the reservoir as well as the hydropower is also used as a floating net cultivation area, irrigation water source, and planned as a source of raw water for the area around the reservoir. The toxicity of metals in humans causes some negative effects, especially tissue damage, detoxifying and excretory organs (liver and kidney). Some metals are carcinogenic, teratogenic, and attack the nerves that shall cause behavioral abnormalities. According to Darmono (2001), the order of heavy metal toxicity from high to low is $\mathrm{Hg}>\mathrm{Cr}>\mathrm{Cd} \sim \mathrm{Cu} \sim \mathrm{Zn}>\mathrm{Ni}$, while for the genotoxicity $\mathrm{Hg}>\mathrm{Cr}>\mathrm{Cu} \sim \mathrm{Cd} \sim \mathrm{Ni}>\mathrm{Zn}$. Meanwhile, according to Adams (2007), the order of metal toxicity in mammals is $\mathrm{Cd}>$ $\mathrm{Pb}>\mathrm{Se}>\mathrm{Hg}>\mathrm{As}>\mathrm{Zn}>\mathrm{Cu}>\mathrm{Ni}$, in birds $\mathrm{Pb}>\mathrm{Se}>\mathrm{Cd}>\mathrm{As}>\mathrm{Hg}>\mathrm{Cu}>\mathrm{Ni}>\mathrm{Zn}$. In addition, the uptake sequence in invertebrates is $\mathrm{Cd}>\mathrm{Cu}>\mathrm{Zn}>\mathrm{Pb}>\mathrm{Ni}$, whereas in plants $\mathrm{Se}>\mathrm{Cd}>\mathrm{Zn}>\mathrm{Hg}>\mathrm{Cu}>\mathrm{Pb}>\mathrm{As}>\mathrm{Ni}$ (Adams, 2007). Heavy metals are bioaccumulation and biomagnification of living things. Bioaccumulation is a continuous build up of contaminants in organs. While biomagnification is the entry of chemicals from the environment through the food chain so that it accumulates to a higher trophic level. Sequence of bioaccumulation potential on soil invertebrates $\mathrm{Cd}>\mathrm{Cu}>\mathrm{Zn}>\mathrm{Pb}$, whereas in earthworms $\mathrm{Cd}>\mathrm{Cu}>\mathrm{Zn}>\mathrm{Pb}>\mathrm{Ni}$ (Adams, 2007). In addition, heavy metals can also accumulate in plants with a sequence of bioaccumulation potentials of $\mathrm{Se}>\mathrm{Cd}>\mathrm{Zn}>\mathrm{Hg}>\mathrm{Cu}>\mathrm{Pb}>\mathrm{As}>\mathrm{Ni}$ (Adams, 2007).

One of the steps to facilitate the depiction of the results of the analysis of the sediment quality of a waters is to create an index. Currently several geochemical indexes have been developed to assess the quality of lake sediments associated with heavy metal contamination. This study will assess the quality of sediment using Igeo, CF, MPI, and PERI methods. Based on the results of the calculation of sediment quality using Igeo method as shown in Table 6. Saguling Reservoir Sediment has been contaminated $\mathrm{Cd}$ with very polluted category during rainy and dry season while for the other three heavy metals $\mathrm{Cr}, \mathrm{Cu}$, and $\mathrm{Pb}$ including Unpolluted to moderated category. High Igeo value for $\mathrm{Cd}$ shows that there has been enrichment of heavy metal concentrations derived from human activities such as industrial activities, agriculture, mining etc.

Table 6. Igeo Value and Category of Heavy Metal Pollution in Sediment Saguling Reservoir

\begin{tabular}{|c|c|c|c|c|c|c|c|c|}
\hline \multirow{2}{*}{$\begin{array}{l}\text { Sampling } \\
\text { Location }\end{array}$} & \multicolumn{2}{|c|}{$\mathrm{Cd}$} & \multicolumn{2}{|c|}{$\mathrm{Cr}$} & \multicolumn{2}{|c|}{$\mathrm{Cu}$} & \multicolumn{2}{|c|}{$\mathrm{Pb}$} \\
\hline & Rainy & Dry & Rainy & Dry & Rainy & Dry & Rainy & Dry \\
\hline $1 \mathrm{~A}$ & 9.72 & 8.25 & 0.30 & 0.34 & 0.43 & 1.06 & 0.20 & 0.80 \\
\hline $1 \mathrm{~B}$ & 9.63 & 6.82 & 0.25 & 0.22 & 0.60 & 0.63 & 0.30 & 0.37 \\
\hline 2 & 9.11 & 6.97 & 0.21 & 0.19 & 0.58 & 0.98 & 0.30 & 0.42 \\
\hline 3 & 8.40 & 7.08 & 0.22 & 0.28 & 0.30 & 0.63 & 0.19 & 0.23 \\
\hline 4 & 9.85 & 7.09 & 0.27 & 0.23 & 0.52 & 0.64 & 0.32 & 0.37 \\
\hline 5 & 9.07 & 5.35 & 0.24 & 0.19 & 0.34 & 0.36 & 0.26 & 0.27 \\
\hline 6 & 8.28 & 5.10 & 0.22 & 0.17 & 0.51 & 0.39 & 0.24 & 0.25 \\
\hline 7 & 9.11 & 6.23 & 0.26 & 0.18 & 0.50 & 0.54 & 0.43 & 0.26 \\
\hline 8 & 8.09 & 4.78 & 0.22 & 0.17 & 0.33 & 0.28 & 0.20 & 0.15 \\
\hline 9 & 8.81 & 5.70 & 0.24 & 0.21 & 0.62 & 0.54 & 0.25 & 0.22 \\
\hline $10 \mathrm{~A}$ & 8.18 & 6.29 & 0.23 & 0.21 & 0.32 & 0.62 & 0.31 & 0.23 \\
\hline $10 \mathrm{~B}$ & 6.74 & 9.13 & 0.17 & 0.30 & 0.25 & 0.66 & 0.30 & 0.21 \\
\hline
\end{tabular}

\begin{tabular}{ccl}
\hline \multicolumn{3}{c}{ Index Geoaccumulation Method } \\
\hline Igeo & Class & \multicolumn{1}{c}{ Sediment Quality } \\
\hline$<0-0$ & 0 & Unpolluted \\
$>0-1$ & 1 & Unpolluted to moderated \\
$>1-2$ & 2 & Moderated polluted \\
$>2-3$ & 3 & Moderated polluted to high polluted \\
$>3-4$ & 4 & Highly polluted \\
$>4-5$ & 5 & Highly to extremely polluted \\
$>5$ & $\geq 6$ & extremely polluted \\
\hline
\end{tabular}

(muller., 1969)

Based on the result of calculation of sediment quality using CF sediment of Saguling Reservoir has contaminated $\mathrm{Cd}$ with very high contamination category during rainy and dry season, contaminated $\mathrm{Cr}$ with low contamination category up to medium contamination in two different seasons. $\mathrm{Cu}$ contaminated with moderate contamination category up to considerable contamination during rainy and dry seasons. Lastly polluted $\mathrm{Pb}$ with low contamination category up to medium contamination in two different seasons. Table 7 presents the $\mathrm{CF}$ grades and categories for heavy metal pollution in Saguling Reservoir Sediments.

Table 7. CF Value and Category of Heavy Metal Pollution in Sediment Saguling Reservoir

\begin{tabular}{ccccccccc}
\hline \multirow{2}{*}{$\begin{array}{c}\text { Sampling } \\
\text { Location }\end{array}$} & \multicolumn{2}{c}{$\mathrm{Cd}$} & \multicolumn{2}{c}{$\mathrm{Cr}$} & \multicolumn{2}{c}{$\mathrm{Cu}$} & \multicolumn{2}{c}{$\mathrm{Pb}$} \\
\cline { 2 - 9 } & Rainy & Dry & Rainy & Dry & Rainy & Dry & Rainy & Dry \\
\hline 1A & 48.41 & 41.10 & 1.49 & 1.71 & 2.14 & 5.27 & 1.00 & 3.97 \\
1B & 48.00 & 34.00 & 1.24 & 1.11 & 3.01 & 3.16 & 1.49 & 1.87 \\
2 & 45.40 & 34.75 & 1.07 & 0.94 & 2.88 & 4.90 & 1.49 & 2.08 \\
3 & 41.85 & 35.29 & 1.10 & 1.41 & 1.47 & 3.13 & 0.92 & 1.15
\end{tabular}

\begin{tabular}{cc}
\hline \multicolumn{2}{c}{ Contamination Factor Method } \\
\hline $\mathrm{CF}$ & Sediment Quality \\
\hline $\mathrm{CF}<1$ & low contamination \\
$1 \leq \mathrm{CF} \geq 3$ & moderate contamination \\
$3 \leq \mathrm{CF} \geq 6$ & considerable contamination \\
$\mathrm{CF}>6$ & very high contamination \\
\hline
\end{tabular}




\begin{tabular}{ccccccccc}
4 & 49.06 & 35.32 & 1.32 & 1.15 & 2.58 & 3.18 & 1.59 & 1.82 \\
5 & 45.21 & 26.65 & 1.22 & 0.94 & 1.70 & 1.79 & 1.29 & 1.37 \\
6 & 41.24 & 25.41 & 1.09 & 0.85 & 2.55 & 1.92 & 1.20 & 1.24 \\
7 & 45.38 & 31.06 & 1.31 & 0.88 & 2.50 & 2.67 & 2.16 & 1.31 \\
8 & 40.32 & 23.81 & 1.09 & 0.83 & 1.65 & 1.39 & 0.98 & 0.73 \\
9 & 43.91 & 28.43 & 1.20 & 1.05 & 3.06 & 2.71 & 1.25 & 1.08 \\
$10 \mathrm{~A}$ & 40.76 & 31.32 & 1.13 & 1.03 & 1.59 & 3.09 & 1.54 & 1.13 \\
$10 \mathrm{~B}$ & 33.60 & 45.49 & 0.86 & 1.47 & 1.23 & 3.31 & 1.50 & 1.06 \\
\hline
\end{tabular}

(Hakanson dkk.,1980)

MPI is a method of assessing sediment quality related to heavy metal pollution using data over one sampling point, this method developed by Thomilson et al (1970). The MPI method is a simple way to assess the sediment quality of a waters such as the Saguling Reservoir. The results of the Saguling Reservoir quality assessment by MPI method are presented in Picture 6. The MPI value for heavy metals $\mathrm{Cd}$ occupies the highest position followed by $\mathrm{Cu}, \mathrm{Pb}$, and $\mathrm{Cd}$. MPI value for $\mathrm{Cd}$ in the rainy season reached 43.38 larger than the dry season of 32.17 , the value of MPI $\mathrm{Cu}$ in the rainy season 2.10 is lower than the dry season 2.85. MPI value for $\mathrm{Cr}$ rainy season is 1.16 bigger than last dry season 1.09 the value of MPI Pb rainy season is 1.33 lower than 1.42 drought. Based on the calculation result by MPI method it can be concluded that the sediment of Saguling Reservoir as a whole has been contaminated by $\mathrm{Cd}, \mathrm{Cr}, \mathrm{Cu}$, and $\mathrm{Pb}$.

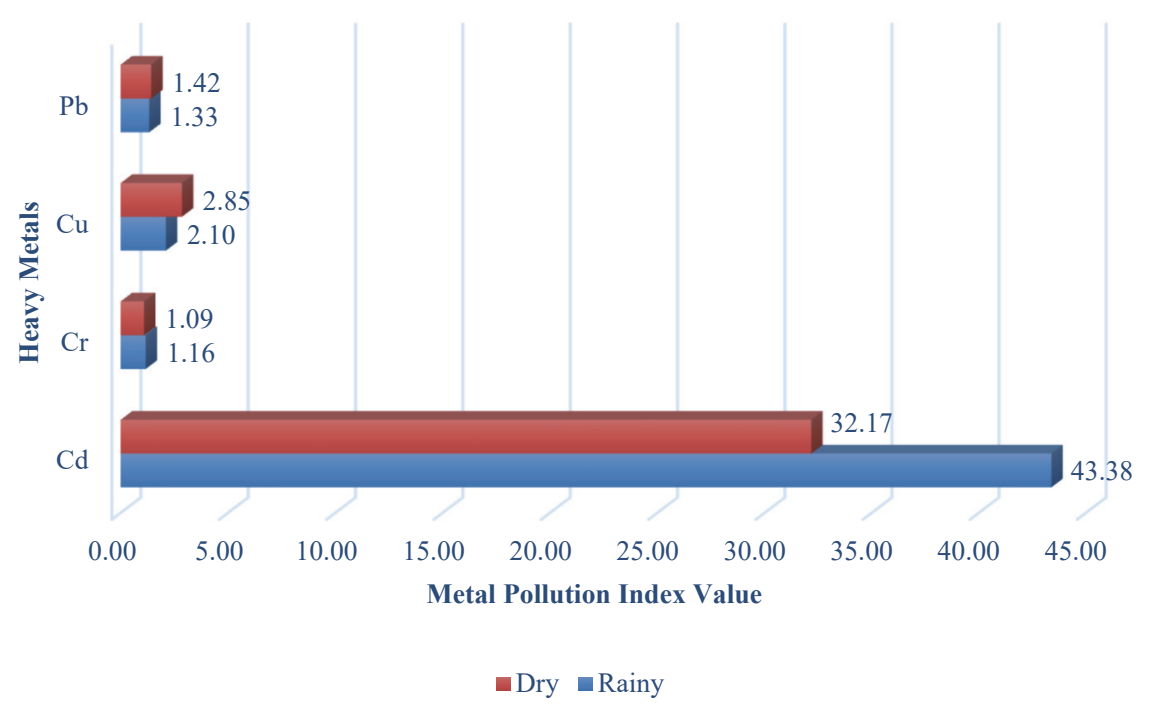

Figure 3. MPI Value for $\mathrm{Cd}, \mathrm{Cr}, \mathrm{Cu}$, and $\mathrm{Pb}$ di Saguling Reservoir Sediment in Dry and Rainy Seasons

Hakanson proposed the PERI in 1980, and it has since been applied to evaluate the harm caused by heavy metals in sediments (Fernandez et al.,1997; Zhu et al.,2012). The heavy metal content of the World was used as the regional background value in this study. The ranking standard of the potential ecological risk index of heavy metals ranged from class 1-4: Class 1 (low-grade ecological risk): PERI $<150$; Class 2 (moderate ecological risk): $150<$ PERI $<300$; Class 3 (severe ecological risk): $300<$ PERI $<600$; and Class 4 (serious ecological risk): PERI $>600$. Based on calculations using PERI it is known that the sediment quality of Saguling Reservoir has been polluted by heavy metal $\mathrm{Cd}$ with serious ecological risk in rainy and dry season, contaminated with $\mathrm{Cr}$ and $\mathrm{Pb}$ with Low grade ecologogical risk category in two different seasons. Saguling Reservoir Sediment has been polluted Cu with the category of Low grade ecological risk risk in the rainy season and Moderate ecological risk in the dry season. Figure 7 explains PERI values for $\mathrm{Cd}, \mathrm{Cr}, \mathrm{Cu}$, and $\mathrm{Pb}$ in Saguling Reservoir sediments during the rainy and dry seasons. 


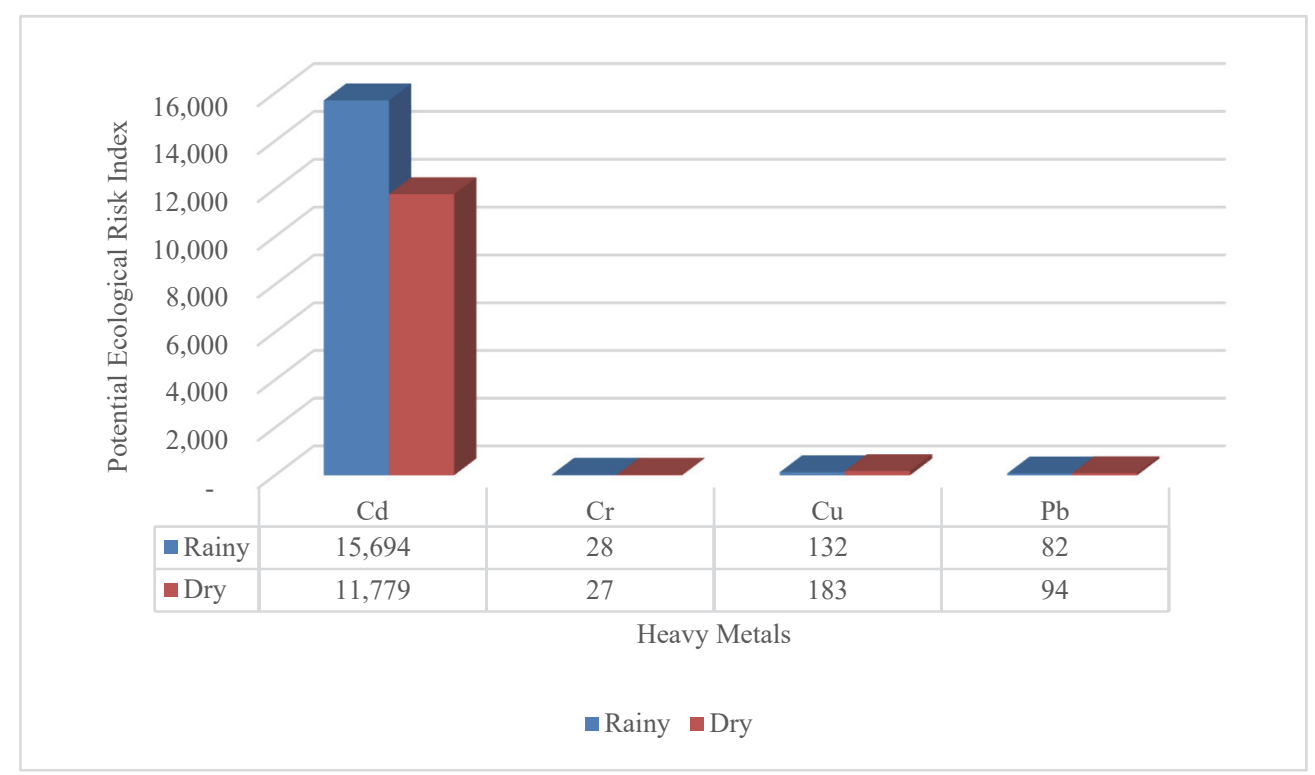

Figure 4. PERI Value for $\mathrm{Cd}, \mathrm{Cr}, \mathrm{Cu}$, and $\mathrm{Pb}$ di Saguling Reservoir Sediment in Dry and Rainy Seasons

After it is known that the sediment quality of Saguling Reservoir has been contaminated by four metals ie $\mathrm{Cd}, \mathrm{Cr}$, $\mathrm{Cu}$, and $\mathrm{Pb}$, it is necessary to overcome the effort so as not to have an impact on the public health around the reservoir. Efforts that can be done with technical and non technical aspects. One of the efforts to manage it by way of wastewater treatment from various sectors, industry, domestic, agriculture and garbage besides it is needed better law enforcement effort to waste generating institution which is in Saguling Reservoir water catchment area.

\section{Conclusion}

Based on the results of this study it can be concluded that the sediment quality of Saguling Reservoir has been contaminated by heavy metals $\mathrm{Cd}, \mathrm{Cr}, \mathrm{Cu}$, and $\mathrm{Pb}$. This is caused by human activity in the water catchment area of the reservoir. Based on the results of the analysis of sediment quality using Igeo and CF sediment Saguling Reservoir has been polluted by heavy metals specifically $\mathrm{Cd}$ in the rainy and dry seasons. The result of assessment of sediment quality by MPI method can be concluded that the sediment of Saguling Reservoir as a whole has been contaminated by $\mathrm{Cd}, \mathrm{Cr}, \mathrm{Cu}$, and $\mathrm{Pb}$. Based on calculations using PERI method, the sediment quality of Saguling Reservoir has contaminated $\mathrm{Cd}$ with serious ecological risk category in rainy and dry season, contaminated with $\mathrm{Cr}$ and $\mathrm{Pb}$ with low grade ecological risk category during rainy and dry season, has been contaminated with $\mathrm{Cu}$ with low grade ecological risk in the rainy season and moderate ecological risk in the dry season. Based on the results of this study shall be cautioned that heavy metal $\mathrm{Cd}$ reach the highest concentration in the rainy season and dry season than three other heavy metals.

\section{Acknowledgment}

This research has been financially supported by State Minister for Research and Technology and Higher Education. Authors thank to all reviewer for valuable input and suggestions.

\section{References}

ANZECC (Australian and New Zealand Environment and Conservation Council) (1997). ANZECC interim sediment quality guidelines.

ANZECC (Australian and New Zealand Environment and Conservation Council) (2003). ANZECC interim sediment quality guidelines.

Beutel, M. W., Leonard, T. M., Dent, S. R., \& Moor, B. C. (2008). Effects of aerobic and anaerobic conditions on $\mathrm{P}, \mathrm{N}, \mathrm{Fe}, \mathrm{Mn}$ and $\mathrm{Hg}$ accumulation in waters overlaying profundal sediments of anoligo mesotrophic lake. Water Res., 42, 1953-1962.

Fernandes, H. M. (1997). Heavy metal distribution in sediments and ecological risk assessment: The role of diagenetic processes in reducing metal toxicity in bottom sediments. Environmental Pollution, 97(3), 317325 
Forghani, G., Moore, F., Lee, S., \& Qishlaqi, A. (2009). Geochemistry and speciation of metals in sediments of the Maharlu Saline Lake, Shiraz, S W Iran. Environ. Earth Sci., 59(1), 173-184.

Gaur, V. K., Gupta, S. K., Pandey, S. D., Gopal, K., \& Misra, V. (2005). Distribution of heavy metals in sediment and water of River Gomti. Environ. Monit. Assess., 102, 419-433.

Hakanson, L. (1980). An ecological risk index for aquatic pollution control: A sedimentological approach. Water Res., 14(8), 975-1001.

Hu, Y., Qi, S. H., Wu, C. X., Ke, Y. P., Chen, J., Chen, W., \& Gong, X. Y. (2012). Preliminary assessment of heavy metal contamination in surface water and sediments from Honghu Lake East central China. Front. EarthSci., 6(1), 39-47.

Karbassi, A. R., Monavari, S. M., Nabi Bidhendi, G. R., Nouri, J., \& Nematpour, K. (2008). Metal pollution assessment of sediment and water in the Shur River. Environ. Monitor. Assess., 147(1-3), 107-116.

Malik, N., Biswas, A. K., Qureshi, T. A., Borana, K, \& Virha, R., (2010). Bioaccumulation of heavy metals in fish tissues of a fresh water lake of Bhopal. Environmental Monitoring and Assessment, 160, 267-276.

Nouri, J., Mahvi, A. H., Jahed, G. R., \& Babaei, A. A. (2008). Regional distribution pattern of ground-water heavy metals resulting from agricultural activities. Environ.Geo., 55(6), 1337-1343.

Reza, R., \& Singh, G. (2010). Heavy metal contamination and its indexing approach for river water. Int. J. Environ. Sci.Tech., 7(4),785-792.

Soemarwoto, edited by Barry A. Costa-Pierce, Otto (1990). Reservoir fisheries and aquaculture development for resettlement in Indonesia. Jakarta, Indonesia: Perusahaan Umum Listrik Negara. p. 21. ISBN 971-10-22508.

Su, L.Y., Liu, J. L., \& Christensen, P. (2011). Spatial distribution and ecological risk assessment of metals in sediments of Baiyangdian Wetland ecosystem. Ecotox ecology, 20, 1107-1116.

Sundaray, S. K., Nayak, B. B., Lin, S., \& Bhatta, D. (2011). Geochemical speciation and risk assessment of heavy metals in the river estuarine sediments a case study: Mahanadi basin India. J. Hazard. Matter., 186(2-3), 18371846.

Tomilson, D. C., Wilson, J. G., Haris. C. R., \& Jefferey, D. W. (1980). Problems in the assessment of heavy metals levels in estuaries and the formation of a pollution index, Helgol. Wiss. Meeresunters, 33, 1-4, 566-575.

Turkerian, K. K., \& Wedepohl, K. H. (1961). Distribution of the elements in soil mayor units of the earth's crust. Bull geol. Soc Am, 72, 175-192

Varol, M., \& Şen, B. (2012). Assessment of nutrient and heavy metal contamination in surface water and sediments of the upper Tigris River, Turkey. Catena, 92, 1-10.

Yin, H., Gao, Y., \& Fan, C., (2011). Distribution, sources and ecological risk assessment of heavy metals in surface sediments from Lake Taihu, China. Environ. Res. Lett., 6, 044012 (11 pp).

\section{Copyrights}

Copyright for this article is retained by the author(s), with first publication rights granted to the journal.

This is an open-access article distributed under the terms and conditions of the Creative Commons Attribution license (http://creativecommons.org/licenses/by/4.0/). 